Reprod. Nutr. Dévelop., 1982, 22 (3), 557-567.

\title{
Plasma iodothyronine levels in lambs during the perinatal period: influence of thyrotropin injection
}

\author{
Marie-Jeanne DAVICCO, J. LEFAIVRE, J.-P. BARLET \\ I.N.R.A., Theix, 63110 Beaumont, France
}

Summary. Plasma thyroxine $\left(T_{4}\right)$ and triiodothyronine $\left(T_{3}\right)$ levels were measured in 7 pregnant ewes and their 9 chronically cannulated foetuses during the last 37 days of gestation and the first 5 days after parturition. The highest plasma $T_{4}$ and $T_{3}$ levels were measured in lambs during the hours following parturition.

In 7 chronically cannulated 139-day old foetal lambs, the intravenous injection of ovine thyrotropin (OTSH ; $7 \mathrm{mU}$ per foetus) induced a significantly more intense increase in plasma $T_{4}$ and $T_{3}$ levels than that observed after the same dose of oTSH in seven 130day old foetuses.

In newborn lambs, the increase in plasma $\mathrm{T}_{4}$ levels after oTSH injection $(3.5 \mathrm{mU}$ per kg body weight) was not different in 8-hour old and 36-hour old animals, but was more intense at $120 \mathrm{~h}$ after birth than at 8 or $36 \mathrm{~h}$ after birth. The rise in plasma $\mathrm{T}_{3}$ levels after oTSH increased with age at 8,36 and $120 \mathrm{~h}$ following birth.

Plasma $T_{4}$ and $T_{3}$ measurements made in the same lambs before and after birth confirmed the fragmentary values obtained in foetal and newborn lambs in other previous studies. The rise in plasma iodothyronine levels after TSH injection in lambs increased at the end of gestation and the beginning of neonatal life, except during the first hours after delivery when these levels were high.

\section{Introduction.}

Studies performed in lambs during the perinatal period suggest that the high plasma iodothyronine levels measured in newborn ovines (Nathanielsz, 1969 ; Davicco, Vigouroux and Barlet, 1980) can be related to several causes: (i) increased thyroid gland secretion of thyroxine $\left(T_{4}\right)$ and triiodothyronine $\left(T_{3}\right)$ (Slebodzinski, 1972 ; Klein, Oddie and Fisher, 1980), (ii) increased hepatic conversion of $T_{4}$ to $T_{3}$ in the newborn compared to the foetus ( $W u$ et al., 1978). The increased $\mathrm{T}_{4}$ secretion observed in the early hours after birth was initially attributed to a thyrotropin (TSH) surge (Fisher et al., 1977); however, serum TSH concentrations are similar before and after birth in lambs (Klein and Fisher, 1980 ), and the $T_{4}$ response to thyroliberin-stimulated TSH release is greater in newborn lambs than in foetuses (Klein and Fisher, 1980). Thus, these latter experiments suggest increased thyroid gland sensitivity to TSH in the newborn (Klein, Oddie and Fisher, 1980). The purpose of the present work was (i) to 
measure simultaneously plasma $T_{4}$ and $T_{3}$ levels in lambs and their dams during the perinatal period and (ii) to compare the response of lambs to TSH given before and after birth.

\section{Material and methods.}

Animals. - We used 21 primiparous Limousine $\times$ Romanov ewes of known gestational age mated with an lle-de-France ram after oestrus synchronization. They were housed on straw in individual pens. Each animal was fed hay $(3 \mathrm{~kg}$ per day) and grain concentrate ( $300 \mathrm{~g}$ per day) and had free access to tap water. The length of gestation for ewes of this genotype in our flock is $145 \pm 2$ days.

Using 14 ewes under halothane anesthesia, between days 100 and 110 of gestation, we chronically implanted into their twin foetuses one catheter in the left carotid artery for blood sampling and one in the right jugular vein for hormone injections. The foetuses of the other 7 ewes 15 with singletons and 2 with twins) only had a catheter implanted in the left carotid artery. The technique, derived from that used by Mellor and Matheson (1975) for chronic catheterization of the umbilical vessels of foetal sheep, has already been described in detail (Barlet et al., 1978). Each ewe delivered a live lamb on days 144 to 147 of gestation. The birth weight of single $(3.6 \pm 0.2 \mathrm{~kg}$; mean \pm SEM) and twin $(3.1 \pm 0.3 \mathrm{~kg})$ lambs was not different from that of the control lambs from unoperated primiparous ewes of the same flock. After birth, the lambs were left with their dams and suckled ad libitum.

To measure plasma $T_{4}$ and $T_{3}$ levels, serial blood samples $(1 \mathrm{ml}$ each) were simultaneously collected from the last 7 ewes (by puncture of the external jugular vein) and from their 9 foetuses during the last 37 days of gestation and the first 5 days after parturition. The other ewes were divided into two groups : 7 were used on day 130 and 7 on day 139 of gestation. Each time, one foetus of each ewe was intravenously injected $(7 \mathrm{mU}$ per foetus) with purified ovine thyrotropin (oTSH ; NIAMDD - oTSH-9; $7.5 \mathrm{lU} / \mathrm{mg}$ ) ; the body weight of 130 to 140-day old foetuses of this genotype is approximately $2 \mathrm{~kg}$. Twin foetuses, used as controls, simultaneously received the same volume of vehicle $(1 \mathrm{ml}$ of sterile 0.9 p. $100 \mathrm{NaCl}$ ).

Three groups of 7 to 8 lambs each were intravenously injected with oTSH (3.5 $\mathrm{mU}$ per $\mathrm{kg}$ body weight) at 8,36 or $120 \mathrm{~h}$ after birth. The lambs were chosen according to their birth time, so that each injection could be given at 9 a.m. Control lambs of the same age received the same volume $10.5 \mathrm{ml}$ per $\mathrm{kg}$ body weight) of vehicle.

The blood of newborn lambs was collected by puncture of the jugular vein opposite to the one in which the oTSH was injected. The plasma was centrifuged and frozen until assay.

Analysis. - Plasma total $\mathrm{T}_{4}$ and $\mathrm{T}_{3}$ concentrations were measured by radioimmunoassay using $T_{3}$ (Trik) and total $T_{4}$ (Tetrak) radioimmunoassay kits from the " Commissariat à l'Energie atomique » (Gif-sur-Yvette, France). Plasma samples of $100 \mu \mathrm{l}$ and $10 \mu \mathrm{l}$ were used for $T_{4}$ and $T_{3}$ determinations, respectively. 
In our experimental conditions, reproducibility was $2 \mathrm{p}$. 100 for the $T_{4}$ assay and sensitivity was $2 \mathrm{ng} / \mathrm{ml}$ of plasma. For the $T_{3}$ assay, reproducibility was $3 \mathrm{p} .100$ and sensitivity was $15 \mathrm{pg} / \mathrm{ml}$ of plasma. No significant interaction with other iodothyronines or iodotyrosines was observed in any assay.

The results were expressed as the mean \pm SEM. Student's t-test or variance analysis was used for statistical comparison.

\section{Results.}

During the last 36 days of gestation, the mean plasma $T_{4}$ level was higher in foetuses $(8.3 \pm 0.4 \mu \mathrm{g} / \mathrm{dl})$ than in ewes $(5.0 \pm 0.3 \mu \mathrm{g} / \mathrm{dl} ; \mathrm{P}<0.01)$. In lambs, plasma $\mathrm{T}_{4}$ levels increased from $5.4 \pm 2.5 \mu \mathrm{g} / \mathrm{dl} 4$ days before term to $11.1 \pm 0.6 \mu \mathrm{g} / \mathrm{dl} \quad(\mathrm{P}<0.05) 2$ days later, decreased to $8.0 \pm 0.6 \mu \mathrm{g} / \mathrm{dl}$ $(\mathrm{P}<0.05) 1$ day before parturition, rose to $14.4 \pm 0.4 \mu \mathrm{g} / \mathrm{dl}$ (P $<0.01) 6 \mathrm{~h}$ after birth, decreased to $7.8 \pm 0.8 \mu \mathrm{g} / \mathrm{dl}(\mathrm{P}<0.01) 48 \mathrm{~h}$ after birth and then remained stable until $120 \mathrm{~h}(8.1 \pm 1.3 \mu \mathrm{g} / \mathrm{dl})$. In ewes, the plasma $T_{4}$ levels were unchanged between day 37 before parturition $(7.0 \pm 1.0 \mu \mathrm{g} / \mathrm{dl})$ and day 5 after parturition $(8.1 \pm 1.3 \mu \mathrm{g} / \mathrm{d}$ ll). Thus, during the first 5 days after birth, the mean plasma $T_{4}$ level was still higher in newborn lambs $(10.3 \pm 0.8 \mu \mathrm{g} / \mathrm{dl})$ than in their dams (5.7 $\pm 0.5 \mu \mathrm{g} / \mathrm{dl} ; \mathrm{P}<0.01$ ) (fig. 1).

Between days -37 and -1 before parturition, the mean plasma $T_{3}$ level was higher in ewes $(150 \pm 8 \mathrm{ng} / \mathrm{dl})$ than in foetuses $(95 \pm 9 \mathrm{ng} / \mathrm{dl}) ; \mathrm{P}<0.01)$, but during the first 5 days after delivery the mean plasma $T_{3}$ level was higher in lambs $(328 \pm 16 \mathrm{ng} / \mathrm{dl})$ than in dams $(185 \pm 12 \mathrm{ng} / \mathrm{dl} ; P<0.01)$. Plasma $T_{3}$

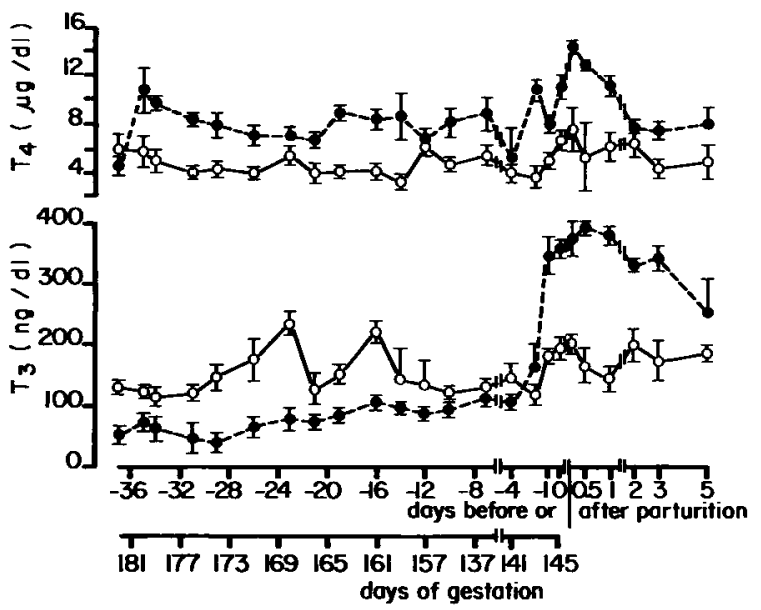

FIG. 1. - Plasma total thyroxine $\left(\mathrm{T}_{4}\right)$ and trï̄odothyronine $\left(\mathrm{T}_{3}\right)$ tevels in 7 ewes (solid lines) and their 9 chronically cannulated foetuses (dashed lines) during the last 37 days of gestation and the 5 days following parturition (mean \pm SEM) 


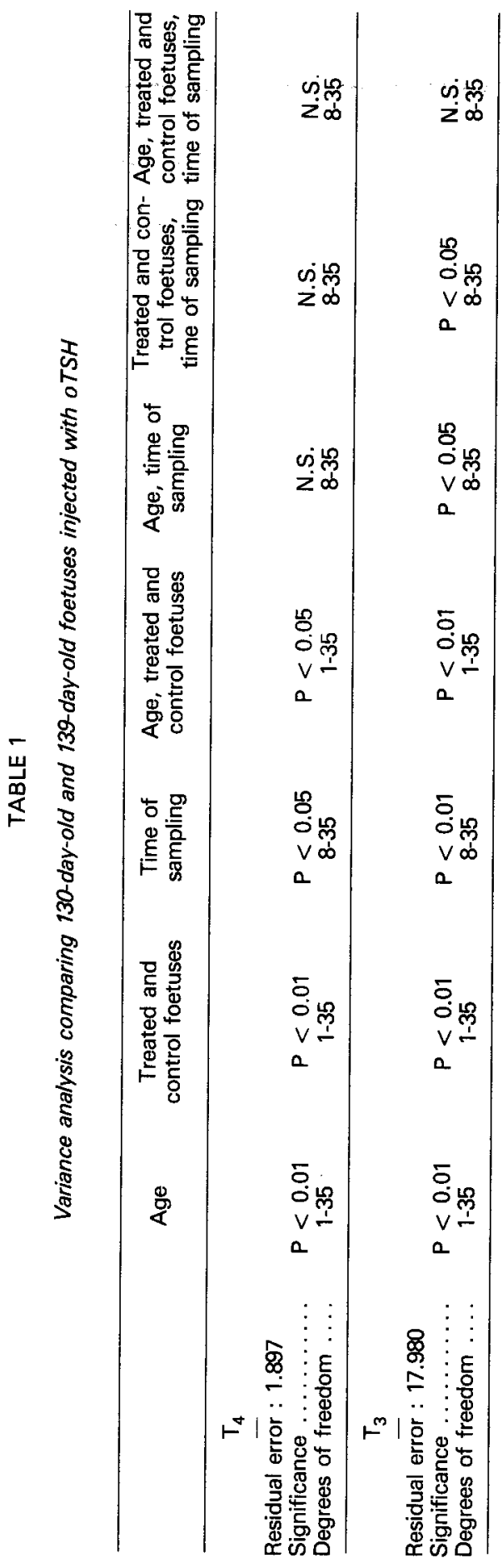


levels increased progressively in lambs between days $-37(53 \pm 8 \mathrm{ng} / \mathrm{dl})$ and -6 $(106 \pm 13 \mathrm{ng} / \mathrm{dl}$ ) before parturition. A marked rise occurred before birth (from -4 to -1 days) with levels around $360 \mathrm{ng} / \mathrm{dl}$. Plasma $T_{3}$ levels then decreased to 249 $\pm 61 \mathrm{ng} / \mathrm{dl}$ on day 5 after parturition (fig. 1). In pregnant ewes, the highest plasma $T_{3}$ levels were measured on days -23 and -16 before parturition $(237 \pm 21$ $\mathrm{ng} / \mathrm{dl}$ and $223 \pm 18 \mathrm{ng} / \mathrm{dl}$, respectively). In these ewes plasma $\mathrm{T}_{3}$ levels increased from $119 \pm 3 \mathrm{ng} / \mathrm{dl} 48 \mathrm{~h}$ before lambing to $205 \pm 8 \mathrm{ng} / \mathrm{dl} 6 \mathrm{~h}$ after lambing $(P<0.01)$ and remained stable until day 5 after parturition $(186 \pm 12$ $\mathrm{ng} / \mathrm{dl}$ ) (fig. 1).

During the $48 \mathrm{~h}$ following injection, no significant variation in plasma $\mathrm{T}_{4}$ and $\mathrm{T}_{3}$ levels was observed in the 7 foetuses injected with oTSH $(7 \mathrm{mU}$ per foetus) on day 130 of gestation. In the 7 foetuses injected with the same dose of oTSH on day 139 of gestation, a 3.5-fold increase in plasma $T_{4}$ levels was observed $3 \mathrm{~h}$ after the injection. Significantly elevated $\mathrm{T}_{4}$ levels were found in these treated 139-day old foetuses from $45 \mathrm{~min}$ to $48 \mathrm{~h}$ after the injection; a 2-fold increase in plasma $T_{3}$ levels, which persisted for $6 \mathrm{~h}$, occurred $2 \mathrm{~h}$ after oTSH injection. The injection of the same volume of vehicle $(1 \mathrm{ml}$ per foetus) in control foetuses was without any effect on foetal plasma iodothyronine levels (table 1 ; figs. $2 a$, b).

The increase in plasma $\mathrm{T}_{4}$ levels after TSH injection was not different in 8hour old and 36-hour old newborn lambs. However, the increase in plasma $T_{3}$ levels following TSH injection was greater in 36-hour old lambs than in 8-hour
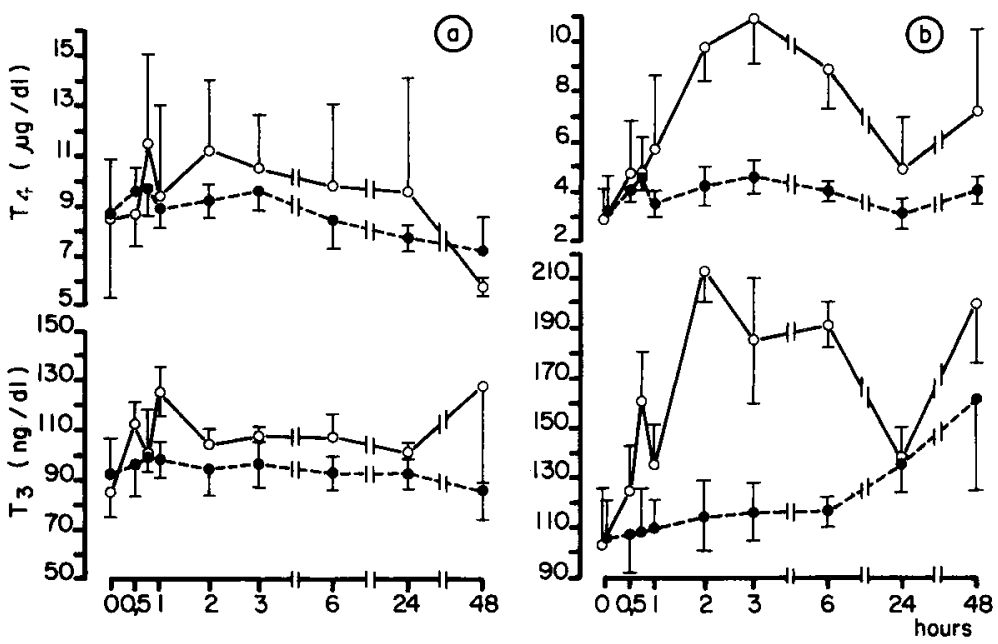

FIG. 2. - Influence of an intravenous injection of oTSH $(7 \mathrm{mU}$ per foetus) in foetal lambs at 130 days (a) and 139 days (b) of gestation. Solid line : treated animals; $n=7$ for each group ; dashed line : twin control lambs; mean \pm SEM. For statistical evaluation see table 1. 
old lambs (table 2 ; figs. 3a, b). Similarly, the rise in plasma $T_{4}$ and $T_{3}$ levels following TSH injection in 120-hour old lambs was more intense than in 8-hour old lambs or 36 -hour old lambs (table 2 ; figs. $3 a, b, c)$.

\section{Discussion.}

Developmental patterns for plasma total $T_{4}$ and $T_{3}$ levels in the ovine species during the perinatal period have already been reported. However, the present study measured, for the first time, changes in both plasma $T_{4}$ and plasma $T_{3}$ levels in the same animals (lambs and ewes) over a long period before and after birth.

Using 2 Merino ewes which lambed after 150 days of gestation, Thorburn and Hopkins (1973). found a significant decrease in foetal plasma $T_{4}$ concentration during the last 10 days before delivery, while Nathanielsz et al. (1973), did not find such changes in foetuses from Welsh Mountain ewes which lambed between 141 and 146 days of gestation. Similarly, Klein, Oddie and Fisher (1978) did not observe a decrease in foetal plasma $T_{4}$ levels during the last 13 days of gestation. Mellor et al. (1976) demonstrated a decrease in the plasma $\mathrm{T}_{4}$ concentration of only 11 out of 21 Scottish Blackface and Welsh Mountain foetuses which had been chronically cannulated. Between days 105 and 129 of gestation, there was no correlation between plasma $T_{4}$ concentration and gestational age in 11 ovine foetuses (Klein and Fisher, 1980). In the 9 foetuses used in the present experiment, born at term on days 144 to 147 of gestation, plasma $\mathrm{T}_{4}$ concentration did not vary significantly between day 36 before parturition and the time of parturition (fig. 1).

The low serum $T_{3}$ in the sheep foetus during days 85 to 140 of gestation is due to a high metabolic clearance rate and decreased production of $T_{4}$ by monodeiodination (Chopra, Sack and Fisher, 1975). Studies in ovine euthyroid maternel-foetal pairs have shown nearly total placental impermeability to labelled $T_{4}$ or labelled $T_{3}$ in both directions ; absolute placental $T_{3}$ transfer was $2 \mu \mathrm{g}$ per day and less than $1.2 \mu \mathrm{g}$ per day in the maternal to foetal and foetal to maternal directions, respectively (Dussault et al., 1972). The rise in plasma $T_{3}$ levels occurring in foetal plasma during the last 4 days of gestation might result from the stimulation of $\mathrm{T}_{4}-\beta$ deiodination induced by the cortisol rise which precedes delivery (Mathur et al., 1980).

In newborn lambs delivered at a low temperature, plasma $T_{3}$ levels increased sharply after birth ; this increase does not appear in lambs delivered in a waterbath at $38{ }^{\circ} \mathrm{C}$ (Fisher et al., 1977). The relatively high external temperature $\left(20^{\circ} \mathrm{C}\right)$ at which the lambs used in this experiment were born and kept during the first week of postnatal life, might explain why there was only a slight increase in foetal plasma $T_{3}$ levels during the hours following delivery (fig. 1).

The plasma TSH level measured in foetal lambs during the last $\mathbf{2 0}$ days of gestation was $3.2 \mathrm{ng} / \mathrm{ml}$ ), i.e. $6.4 \mathrm{mU} / \mathrm{dl}$ (Hopkins, Wallace and Thorburn, 1975). We can thus assume that our treated foetuses were injected with a 
physiological dose of oTSH (7 mU per foetus). Such a dose of oTSH injected into foetuses had no effect on maternal thyroxinemia or triiodothyroninemia. As already demonstrated (Fisher et al., 1977), iodinated bovine TSH does not cross the ovine placenta. When TSH-releasing hormone (TSH-RH) $(50 \mu \mathrm{g})$ was injected into chronically catheterized sheep foetuses between days 113 and 144 of gestation, no effect was observed on plasma $T_{3}$ and $T_{4}$ levels in 113 to 130 day old foetuses, while in 144-day old foetuses, plasma $T_{3}$ increased from 37 $\mathrm{ng} / \mathrm{dl}$ to $90 \mathrm{ng} / \mathrm{dl}$ in $120 \mathrm{~min}$ (Wallace et al., 1979).

In three 1 to 6-day old lambs, plasma $T_{4}$ concentration increased between 60 and 120 min after TSH-RH injection ; the 6-day old lamb, but not the 1 or 2-day old animal, showed a consistent increase in plasma $T_{3}$ concentration in response to TSH-RH injection (Wallace et al., 1979). In our experiment, oTSH injection significantly increased plasma $T_{4}$ and $T_{3}$ levels in each group of newborn lambs (fig. 3 ; table 2).
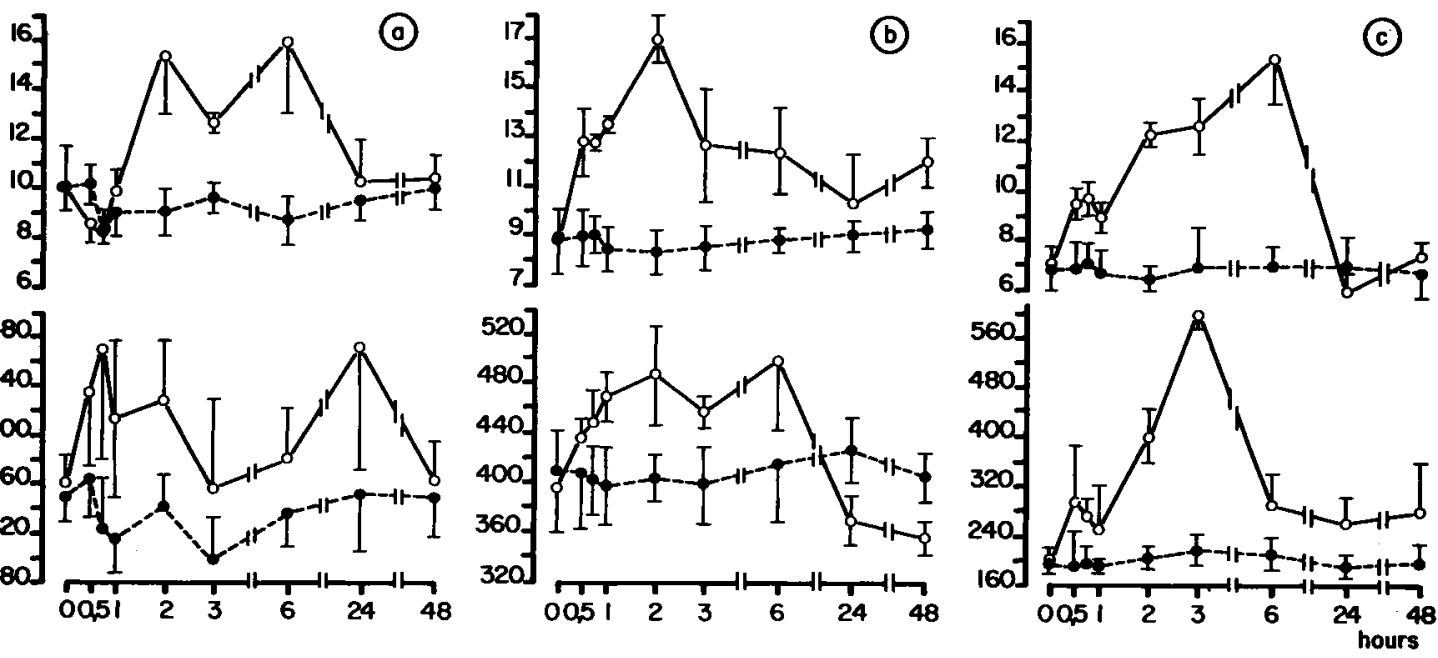

FIG. 3. - Influence of an intravenous injection of oTSH $(3.5 \mathrm{mU}$ per $\mathrm{kg}$ body weight) on plasma thyroxine $\left(\mathrm{T}_{4}\right)$ and triiodothyronine $\left(\mathrm{T}_{3}\right)$ levels in newborn lambs at $8 h$ (a), $36 \mathrm{~h}$ (b) and $120 \mathrm{~h}$ (c) after birth. Solid line : 7 treated animals in each group ; dashed line : 7 control lambs in each group ; mean \pm SEM. For statistical evaluation see table 2 .

The iodothyronine level in the blood represents the ratio of iodothyronine secretion to its metabolic clearance rate. In foetal lambs, $T_{4}$ utilization increased from $0.33 \mu \mathrm{g}$ per hour per $\mathrm{kg}$ of body weight to $0.73 \mu \mathrm{g}$ per hour per $\mathrm{kg}$ of body weight between days 111 and 139 of gestation (Nathanielsz et al., 1973), while in newborn lambs it decreased from $0.6 \pm 0.08 \mu \mathrm{g}$ per hour per $\mathrm{kg}$ of body weight to $0.2 \pm 0.04 \mu \mathrm{g}$ per hour per $\mathrm{kg}$ of body weight between days 3 to 4 and 10 to 11 of postnatal life (Nathanielsz, 1970). Thus, the increasing effect of TSH on plasma $T_{4}$ levels between days 130 and 139 of gestation would result from 


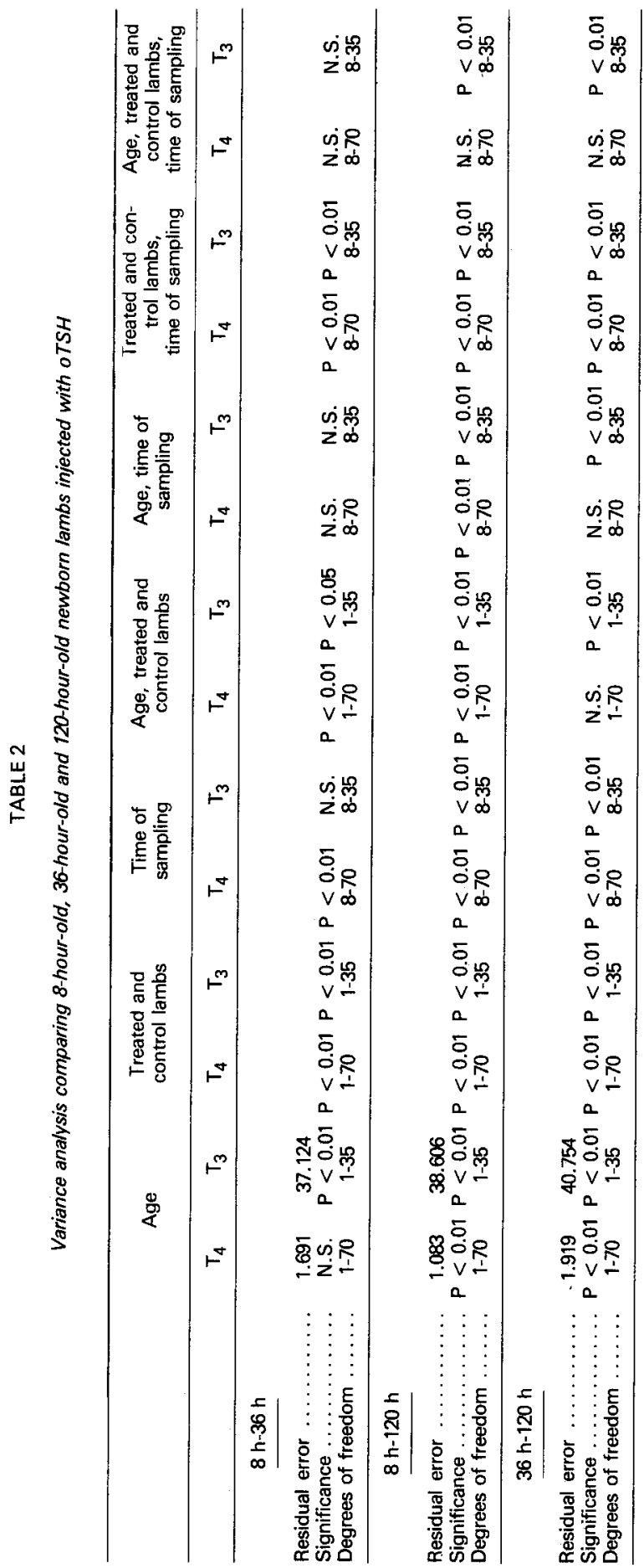


increased thyroid $\mathrm{T}_{4}$ secretion. In newborn lambs, the maximal increase in plasma $T_{4}$ levels occurred in 5-day old animals (fig. 3). This could also partly result from decreased $T_{4}$ utilization in these animals. The metabolic clearance rate for $T_{3}$ was $40 \pm 51$ per $\mathrm{m}^{2}$ per day in 7-day old lambs (Klein, Oddie and Fisher, 1980), significantly less than in 95 to 140-day old foetuses where it was $80.2 \pm 8.91$ per $\mathrm{m}^{2}$ per day (Chopra, Sack and Fisher, 1975). However, to our knowledge, nobody has measured the changes in the metabolic clearance rate of $\mathrm{T}_{3}$ throughout foetal and neonatal life in the ovine species. Thus, we cannot decide whether the increasing effect of oTSH with age in foetal and neonatal lambs mainly results from increasing sensitivity of follicular cells to TSH throughout foetal and neonatal life, and/or from a simultaneous decreasing metabolic clearance rate of $T_{3}$.

It is also interesting to note that the effect of TSH on plasma $T_{4}$ and $T_{3}$ levels was more intense in 139-days old foetuses than in 130-day old ones; basal plasma $\mathrm{T}_{4}$ and $\mathrm{T}_{3}$ levels were $2.9 \pm 1.3 \mu \mathrm{g} / \mathrm{dl}$ and $103 \pm 23 \mathrm{ng} / \mathrm{dl}$, respectively, in the former ; they were $8.5 \pm 3.3 \mu \mathrm{g} / \mathrm{dl}$ and $85 \pm 11 \mathrm{ng} / \mathrm{dl}$, respectively, in the latter. Similarly, basal plasma $T_{4}$ and $T_{3}$ levels were lower in 120-hour old lambs than in 8-hour old newborn lambs. Therefore, in foetuses as in newborn lambs, the lowest basal iodothyronine levels were associated with an increasing TSH effect on plasma $T_{3}$ and $T_{4}$ levels. Studies from several laboratories suggest that circulating $T_{4}$ and $T_{3}$ regulate thyroid function by a feed-back mechanism wherein the iodothyronines act directly on the gland to inhibit its responses to TSH stimulation (Cortell and Rawson, 1944 ; Yu et al., 1976 ; Goldenheim et al., 1979). Thus, the high levels of circulating $T_{4}$ and $T_{3}$, measured in lambs during the hours after birth (fig. 1), might partly explain the decreased response to the oTSH measurement in 8-hour old and 36-hour old lambs. Secondly, in rats thyroidal TSH receptors are regulated by endogenous TSH; after exposure to TSH, the thyroid lobes show decreased responsiveness to the hormone (Witte and McKenzie, 1981). Therefore, the neonatal TSH surge described in lambs (Fisher et al., 1977) would also decrease the response of 8-hour old and 36-hour old lambs to exogenous TSH. Since the development of the foetal hypothalamicpituitary-thyroid axis takes place between 120 days of gestation and 1 to 2 postpartum weeks (Fisher et al., 1977), it is not complete at 130 days of gestation. This could also explain the decreased response to oTSH in 130-day old foetuses.

In conclusion, our results confirm previous fragmentary results obtained by other groups using few animals. They demonstrate that the injection of a physiological dose of ovine TSH in chronically cannulated ovine foetuses and newborn lambs significantly increased the plasma $T_{4}$ and $T_{3}$ levels in 139-day old foetuses and 5-day old lambs, while it had less effect in 130-day old foetuses and 8 to 36 -hour old lambs. This suggests increased thyroid gland sensitivity to TSH at the end of gestation and the beginning of neonatal life, except during the first postpartum hours, which are characterized by high plasma levels of iodothyronines. 
Acknowledgements. - This work was supported by a grant from " Recherches programmées sur la périnatalité ". The animals used in the study were supplied by the "Laboratoire de production ovine ". The generous gift of ovine thyrotropin by the NIAMDD is gratefully acknowledged.

Résumé. Les taux plasmatiques de thyroxine $\left(T_{4}\right)$ et de triiodothyronine $\left(T_{3}\right)$ ont été mesurés chez 7 brebis gestantes primipares et leurs 9 foetus (cathétérisés chroniquement in utero) durant les derniers 37 jours de gestation et les 5 jours suivant la parturition. Les plus fortes thyroxinémie $(14 \mathrm{ng} / \mathrm{dl})$ et triiodothyroninémie $(370 \mathrm{ng} / \mathrm{dl})$ ont été mesurées chez les nouveau-nés 6 heures après la naissance.

Chez 7 fœtus de 139 jours, I'injection intraveineuse de TSH ovine (7 mU par fœetus) induisait une élévation de $T_{4}$ et $T_{3}$ plus intense que celle observée avec une dose analogue de TSH chez 7 fotus de 130 jours.

Chez les agneaux nouveau-nés, l'élévation de la $T_{4}$ plasmatique consécutive à une injection de TSH ovine (3,5 mU par $\mathrm{kg}$ de poids vif) n'était pas différente chez 7 agneaux de $8 \mathrm{~h}$ et chez 7 agneaux de $36 \mathrm{~h}$, mais elle était plus intense chez 7 agneaux de $120 \mathrm{~h}$. L'élévation de la triiodothyroninémie consécutive à TSH augmentait avec l'âge des animaux entre $8 \mathrm{~h}$ et $120 \mathrm{~h}$ après la naissance.

En conclusion, les mesures de $T_{4}$ et $T_{3}$ réalisées sur les mêmes animaux avant et après la naissance confirment des résultats fragmentaires obtenus précédemment par d'autres auteurs. Nos résultats démontrent également que l'élévation des iodothyronines plasmatiques consécutive à une injection de TSH se fait plus intense en fonction de l'âge du fœtus et du nouveau-né, à l'exception des heures suivant la parturition où les taux plasmatiques de $T_{3}$ et $T_{4}$ sont élevés.

\section{Références}

BARLET J.-P., DAVICCO M.-J., LEFAIVRE J., GAREL J.-M., 1978. Endocrine regulation of plasma phosphate in sheep foetuses with catheters implanted in utero. Adv. Exp. Med. Biol., 103. 243-256.

CHOPRA I. J., SACK J., FISHER D. A., 1975. 3,3', $5^{\prime}$-triiodothyronine (reverse $T_{3}$ ) and $3,3^{\prime}, 5-$ triiodothyronine $\left(T_{3}\right)$ in fetal and adult sheep: studies of metabolic clearance rates, production rates, serum binding, and thyroidal content relative to thyroxine. Endocrinology, 97, 1080-1088.

CORTELL R., RAWSON R. W., 1944. The effect of thyroxin on the response of the thyroid gland to thyrotropic hormone. Endocrinology, 35, 488-495.

DAVICCO M.-J., VIGOUROUX E., BARLET J.-P., 1980. Reiationships between birthweight and plasma thyroxine, triiodothyronine and iodide concentration in lambs. J. Develop. Physiol., 2, 53-58.

DUSSAULT J. H., HOBEL C. J., DISTEFANO J. J., ERENBERg A., FISHER D. A., 1972. Triiodothyronine turnover in maternal and fetal sheep. Endocrinology, 90, 1301-1308.

FISHER D. A., DUSSAULT J. H., SACK J., CHOPRA I. J., 1977. Ontogenesis of hypothalamicpituitary-thyroid function and metabolism in man, sheep, and rat. Rec. Progr. Horm. Res., 33, 59-116.

GOLDENHEIM P. D., AMIR S. Y., UCHIMURA H., INGBAR S. H., 1979. Studies of the binding of thyroid hormones and their short loop feedback effects in bovine thyroid tissue. Endocrinology, 105, 130-131.

HOPKINS P. S., WALLACE A. L. C., THORBURN G. D., 1975. Thyrotrophin concentrations in the plasma of cattle, sheep and foetal lambs as measured by radioimmunoassay. J. Endocr., 64, 371-387.

KLEIN A. H., FISHER D. A., 1980. Thyrotropin-releasing hormone-stimulated pituitary and thyroid gland responsiveness and 3,5,3'-triiodothyronine suppression in fetal and neonatal lambs. Endocrinology, 106, 697-701. 
KLEIN A. H., ODDIE T. H., FISHER D. A., 1978. Effect of parturition on serum iodothyronine concentrations in fetal sheep. Endocrinology, 103, 1453-1457.

KLEIN A. H., ODDIE T. H., FISHER D. A., 1980 . lodothyronine kinetic studies in newborn lambs. J. develop. Physiol., 2, 29-36.

MATHUR H., BROWN B. L., KRANE E. J., THOMAS A. L., NATHANIELSZ P. W., 1980. Thyroid hormone relationships in the fetal and newborn lamb. Biol. Neonate, 37, 138-144.

MELLOR D. J., MATHESON I. C., 1975. Chronic catheterization of the aorta and umbilical vessels of fetal sheep. Res, vet. Sci., 18, 221-223.

MELLOR D. J., MATHESON I. C., SMALL J., WRIGHT H., 1976. Plasma thyroxine concentrations in ewes and their fetuses during the last six weeks of pregnancy. Res. vet. Sci., 21, 102-103.

NATHANIELSZ P.W., 1969. Plasma thyroxine levels in the young lamb from birth to 61 days. J. Endocr., 45, 475-476.

NATHANIELSZ P. W., 1970. Thyroxine utilization in the newborn lamb. J. Physiol. (London), 211, 157-171.

NATHANIELSZ P. W., COMLINE R. S., SILVER M., THOMAS A. L., 1973. Thyroid function in the foetal lamb during the last third of gestation. J. Endocr., 58, 535-546.

SLEBODZINSKI A., 1972. Acute depletion of the hormonal-iodine stores from the thyroid gland after birth in lambs. J. Endocr., 53, 195-200.

THORBURN G. D., HOPKINS P. S., 1973. Thyroid function in the foetal lamb, 488-507. In : Foetal and neonatal physiology, R. S. COMLINE, K. W. CROSS, G. S. DAVES, P. W. NATHANIELSZ, Cambridge Univ. Press, London.

WALLACE A. L. C., NANCARROW C. D., EVISON B. M., RADFORD H. M., 1979. The effect of thyrotrophin releasing hormone on pituitary and thyroid function in pre- and post-natal lambs. Acta endocrinol., 92, 119-129.

WITTE A., McKENZIE J. M., 1981. Regulation of the rat thyrotropin receptor in vitro. Endocrinology, 108, 305-309.

WU S. Y., KLEIN A. H., CHOPRA I. J., FISHER D. A., 1978. Alterations in tissue thyroxine-5' monodeiodinating activity in perinatal period. Endocrinology, 103, 235-239.

YU S., FRIEDMAN Y., RICHMAN R., BURKE G., 1976. Altered thyroidal responsitivity to thyrotropin induced by circulating thyroid hormones. J. clin. Invest., 57, 745-755. 